\title{
Effects of contamination and climate in the Pediatric Emergency Department visits for acute respiratory infection in the City of Buenos Aires
}

\author{
Fernando Ferrero, M.D. ${ }^{a}$, Rosana Abrutzky, B.S. ${ }^{b}$, María F. Ossorio, M.D. ${ }^{c}$ and \\ Fernando Torres, M.D. ${ }^{c}$
}

\begin{abstract}
Introduction: Pollution and climate have an impact on pediatric respiratory diseases; few studies have assessed this in the Autonomous City of Buenos Aires.

Objective: To assess the impact of the interaction between air pollutants and climate on the Emergency Department visits for acute lower respiratory tractinfection (ALRTI) in a children's hospital.

Methods: Ecological, time-series study with generalized additive models that included total visits and visits for ALRTI to the Emergency Department between 2012 and 2016. A series with 7-day moving averages for ALRTI visits was founded as a bias control measure. Predictors were daily levels of air pollutants (carbon monoxide, nitrous dioxide, particulate matter $<10 \mu$ ) and meteorological variables (temperature, humidity). Pollutants were measured at three monitoring stations. Temporal variables (day of the week, warm/ cold semester) were controlled.

Results: There were 455256 total visits; 17298 accounted for visits for ALRTI. A correlation was established only between total visits and day of the week (Mondays and Saturdays, more visits; Thursdays, less visits). Less visits for ALRTI were recorded in the warm semester compared to the cold semester (relative risk $=0.23 ; 95 \%$ confidence interval: $0.29-0.18 ; p<0.001$ ).

One monitoring station did not show any correlation; the other two stations showed a weak correlation between carbon monoxide and particulate matter $<10 \mu$ and visits for ALRTI. Conclusion: The season accurately accounts for the increased number of total visits and visits for ALRTI. Although there was a correlation between the level of certain pollutants and the number of visits, its impact was irrelevant.

Key words: air pollution, climate, respiratory tract infections, child.
\end{abstract}

http: / / dx.doi.org/10.5546/aap.2019.eng.368

This research has been funded, in part (FF), by a grant from the Health Research Council, Government of the Autonomous City of Buenos Aires.

Conflict of interest: None.

Received: 10-24-2018 Accepted: 5-27-2019

To cite: Ferrero F, Abrutzky R, Ossorio MF, Torres F. Effects of contamination and climate in the Pediatric Emergency Department visits for acute respiratory infection in the City of Buenos Aires. Arch Argent Pediatr 2019;117(6):368-374

\section{INTRODUCTION}

Acute lower respiratory tract infections (ALRTIs) are a major cause of pediatric morbidity and mortality and the most common reason for visits to the Emergency Department in pediatrics. ${ }^{1}$

In recent years, two threats have emerged worldwide: air pollution and climate change. ${ }^{2}$ The relation between pollution, climate, and visits for respiratory diseases in children, especially in urban areas, is well known. ${ }^{3,4}$ An association has been established between the season and respiratory syncytial virus (RSV) circulation at a local level. ${ }^{5}$

The World Health Organization (WHO) has estimated that urban pollution caused 3700000 premature deaths in 2012 (80\%, in middle- and low-income countries). The pediatric population is a vulnerable group to climate factors. ${ }^{7}$

Few studies have assessed the interaction among environmental pollution, climatic variations, and respiratory disease in the Autonomous City of Buenos Aires (CABA). Most studies have been conducted in Europe or the United States of America (USA), but their results may not be extrapolated to our setting due to differences in pollutants, climatic aspects, and the health status of the exposed population. . $^{8,9}$

There is local evidence that air pollutants, in combination with climate, may constitute a health hazard in the adult population..$^{10}$ It is necessary to assess the impact of these outcome measures on the health of particularly vulnerable subgroups.

The data of a recent study that assessed the relationship between 
environmental pollutants, climate, and visits to the Emergency Department (some of which are included in this report) indicate that climate was the main determinant of the number of total visits. ${ }^{11}$ However, due to the influence of air pollution and climate on respiratory health, ${ }^{12}$ it is possible that visits for such specific condition develope a different pattern.

The objective of this study was to assess if there was a correlation among air pollution levels in the CABA, climatic variables, and the number of visits for ALRTI to the Emergency Department of a children's hospital.

\section{METHODS}

Design: Ecological, time-series study with generalized additive models (GAMs).

Population: Patients who visited the Emergency Department of Hospital General de Niños "Pedro de Elizalde" (HGNPE) in the study period (2012-2016).

Climate data: These were obtained from the National Weather Service, Central Station ("Villa Ortúzar").

Pollution data: These were obtained from the Environmental Protection Agency of the Autonomous City of Buenos Aires, as recorded by three automatic monitoring stations located in different areas of the CABA: "Parque Centenario" (residential area), "Avenida Córdoba" (hightraffic area), and "La Boca" (urban industrial area). ${ }^{13}$ Twenty-four-hour averages were used. ${ }^{14}$

Visit data: These were obtained from the record books of visits to the Emergency Department and the registry of visits for ALRTI to the Emergency Department of HGNPE.

\section{Study outcome measures:}

- Carbon monoxide (CO): CO levels in outside air, in parts per billion (ppb)/ parts per million (ppm). Daily average.

- Nitrous dioxide $\left(\mathrm{NO}_{2}\right): \mathrm{NO}_{2}$ levels in outside air, in parts per million (ppm). Daily average.

- Particulate matter $<10 \mu\left(\mathrm{PM}_{10}\right)$ : Solid or liquid particles with a diameter of less than 10 microns, expressed as $\mu \mathrm{g} / \mathrm{m}^{3}$. Daily average.

- Mean temperature: Average temperatures recorded in the 24 hours of each day, in degrees Celsius $\left({ }^{\circ} \mathrm{C}\right)$.

- Maximum temperature: Highest temperature value recoded in the 24 hours of each day. In degrees Celsius $\left({ }^{\circ} \mathrm{C}\right)$.

- Minimum temperature: Lowest temperature value recorded in the 24 hours of each day. In degrees Celsius $\left({ }^{\circ} \mathrm{C}\right)$.

- Relative humidity: Percentage of water vapor in the air relative to the amount of water vapor in the air that is required to saturate the air in the same pressure and temperature conditions.

- Cold/warm semester: The National Weather Service definition was used. For the CABA, April, May, June, July, August, and September make up the cold semester, and the rest of the months, the warm semester.

\section{Outcome variables:}

Visits for ALRTI: Number of unscheduled visits to the Emergency Department of HGNPE recorded as ALRTI each day. In addition, a series with moving averages was developed; this procedure is used in time-series analysis to smooth potential biases, considering the average of a specific period as the value for each moment. In this case, a 7-day moving mean was used, considering a potential load bias related to the days of the week.

Total visits: Number of unscheduled visits to the Emergency Department of HGNPE each day, regardless of diagnosis.

Analysis: A time-series analysis was done based on the regression analysis between temporal variables (pollution, climate), taken as independent variables, and number of visits, as dependent variables. ${ }^{15}$ Lags of up to 7 days were considered (a lag was defined as the period between the change in a variable and its effects on other variables; in this case, between a change in pollutants or temperature and the change in the number of visits). GAMs ${ }^{16}$ were used for nonparametric as well as parametric smoothing. Different models were tested and GAMs with a quasi-Poisson distribution showed the best results.

Ethical aspects: Approval was requested and obtained from the Research Ethics Committee of HGNPE. The study was registered in the Central Registry of Research Projects of the Ministry of Health of the Autonomous City of Buenos Aires (199/2017).

\section{RESULTS}

Complete series of visits to the Emergency Department were used, total and for ALRTI. Series of 1697 records were established (Table 1).

The series of primary outcome measures (total visits and visits for ALRTI) displayed different behaviors in relation to temporal variables (day, 
month, station, and warm/ cold semester). The series of total visits showed a correlation with the day of the week; Mondays and Saturdays with a higher average of visits (relative risk $[R R]=1.13$; $95 \%$ confidence interval [CI]: 1.09-1.18; and $\mathrm{RR}=1.13 ; 95 \% \mathrm{CI}: 1.09-1.17$, respectively), and Thursdays with a lower average $(\mathrm{RR}=0.94$; $95 \%$ CI: 0.98-0.90). No variation was observed in relation to the visits for ALRTI and the day of the week.

Fewer visits were recorded in the warm semester than in the cold semester, both total $(\mathrm{RR}=0.79 ; 95 \% \mathrm{CI}: 0.77-0.81 ; p<0.001)$ and for ALRTI ( $R R=0.23 ; 95 \%$ CI: 0.29-0.18; $p<0.001)$.

The series of pollutants (Tables 2 and 3 ) measured at "Parque Centenario" station did not show significant correlations with any of the outcome variables. The analysis of the other two stations showed a correlation between increased $\mathrm{CO}$ and $\mathrm{NO}_{2}$ and total visits, with different lags by station and compound. The most important effect was related to $\mathrm{CO}$ : a $10-\mathrm{ppb} \mathrm{CO}$ increase at "Avenida Córdoba" station correlated with a more than $2 \%$ increase in the number of visits between the following day and day 7 , which peaked on day 6 with a $2.5 \%$ increase in the number of visits. The increase in $\mathrm{CO}$ levels measured at "La Boca" station peaked on day 3, when a $2.3 \%$ increase in the number of total visits was confirmed. $\mathrm{NO}_{2}$ levels measured at "La Boca" station also showed a correlation with the total visits: 2 days after a 10-ppb $\mathrm{NO}_{2}$ increase, the number of visits increased $3.5 \%$. $\mathrm{PM}_{10}$ showed negative correlations with the total visits for all the lags analyzed at "Avenida Córdoba" and "La Boca" stations.

In relation to visits for ALRTI, the series showed correlations with $\mathrm{CO}$, which increased $5.2 \% 3$ days after the $10-\mathrm{ppb}$ increase measured at "Avenida Córdoba" station and $9.5 \%$ after 6 days. The 10-ppb CO increase at "La Boca" station correlated with the $13 \%$ increase in visits for ALRTI after 5 days, but this was not consistent over the days. $\mathrm{NO}_{2}$ exhibited negative correlations at "Avenida Córdoba" station and not significant correlations at "La Boca" station. Finally, $\mathrm{PM}_{10}$ showed a weak but consistent correlation in the same and the following day, with a $5.5 \%$ increase in the same day and a mildly lower increase the following day after an increase of $10 \mu \mathrm{g} / \mathrm{m}$ in $\mathrm{PM}_{10}$ levels at "Avenida Córdoba" station.

\section{DISCUSSION}

Our study has verified that the season accurately accounts for the increased number of total visits to the Emergency Department of a children's hospital, specifically for ALRTI, whereas, although air $\mathrm{CO}$ and $\mathrm{NO}_{2}$ levels show a

TABLE 1. General characteristics of primary variables (daily values)

\begin{tabular}{|c|c|c|c|c|}
\hline & Minimum & Mean & Maximum & SD \\
\hline Visits & 60 & 249.58 & 527 & 63.93 \\
\hline ALRTI & 0 & 4.44 & 40 & 7.31 \\
\hline ALRTI mm7 & 0 & 4.46 & 21.29 & 5.01 \\
\hline Minimum temp. $\left({ }^{\circ} \mathrm{C}\right)$ & 0.1 & 13.8 & 28.2 & 5.72 \\
\hline Mean temp. $\left({ }^{\circ} \mathrm{C}\right)$ & 3.7 & 18.06 & 32.7 & 5.86 \\
\hline Maximum temp. $\left({ }^{\circ} \mathrm{C}\right)$ & 7.4 & 23.06 & 39 & 6.29 \\
\hline Relative humidity (\%) & 39 & 72.56 & 100 & 12.24 \\
\hline P. Centenario, CO (ppb) & 10 & 540 & 2600 & 220 \\
\hline Av. Córdoba, CO (ppb) & 10 & 560 & 1800 & 280 \\
\hline La Boca, CO (ppb) & 10 & 220 & 1300 & 160 \\
\hline P. Centenario, $\mathrm{PM}_{10}\left(\mu \mathrm{g} / \mathrm{m}^{3}\right)$ & 4 & 29.61 & 134 & 12.84 \\
\hline Av. Córdoba, $\operatorname{PM}_{10}\left(\mu \mathrm{g} / \mathrm{m}^{3}\right)$ & 7 & 27.51 & 140 & 10.43 \\
\hline La Boca, $\mathrm{PM}_{10}\left(\mu \mathrm{g} / \mathrm{m}^{3}\right)$ & 7 & 25.1 & 126 & 11.02 \\
\hline P. Centenario, $\mathrm{NO}_{2}(\mathrm{ppb})$ & 5 & 17.88 & 50 & 5.82 \\
\hline Av. Córdoba, $\mathrm{NO}_{2}(\mathrm{ppb})$ & 2 & 34.67 & 103 & 19.85 \\
\hline La Boca, $\mathrm{NO}_{2}(\mathrm{ppb})$ & 2 & 15.59 & 75 & 8.36 \\
\hline
\end{tabular}

SD: standard deviation.

ALRTI: acute lower respiratory tract infection.

ALRTI mm7: visits for acute lower respiratory tract infection, 7-day moving mean.

ppb: parts per billion.

CO: carbon monoxide.

$\mathrm{PM}_{10}$ : particulate matter $<10 \mu$.

$\mathrm{NO}_{2}$ : nitrous dioxide.

P. Centenario, Av. Córdoba, La Boca: automatic environmental monitoring stations. 
correlation with the number of visits, their impact on this factor is not relevant.

There is evidence that air pollution may affect children's health, particularly respiratory tract diseases. A study conducted in São Paulo (Brazil) observed that exposure to air pollutants increased the number of visits to an emergency department for asthma and bronchiolitis in children, both on the same day and with some lags. ${ }^{17}$ However, a previous study carried out in Buenos Aires observed that the increase in the studied pollutant levels did not have a significant impact on the number of total visits to the emergency department of a children's hospital. ${ }^{11}$ In this case, it was also verified that this did not occur when considering visits for ALRTI specifically.

The CABA automatic monitoring network includes three stations, which are strategically located in three areas with distinct characteristics that reflect different environmental scenarios:

TABLE 2. Risk for general visits and visits for acute lower respiratory tract infection based on pollutant increase, considering each monitoring station (same day and 1-, 2-, and 3-day lags)

\begin{tabular}{|c|c|c|c|c|c|c|c|c|c|c|}
\hline & & & \multicolumn{2}{|l|}{ Same day } & \multicolumn{2}{|l|}{ 1-day lag } & \multicolumn{2}{|l|}{ 2-day lag } & \multicolumn{2}{|l|}{ 3-day lag } \\
\hline & & & \begin{tabular}{|l} 
RR \\
$\mathrm{Cl}(\mathrm{L}-\mathrm{U})$
\end{tabular} & Signif. & \begin{tabular}{|l} 
RR \\
CI (L-U)
\end{tabular} & Signif. & $\begin{array}{l}\text { RR } \\
\mathrm{Cl}(\mathrm{L}-\mathrm{U})\end{array}$ & Signif. & \begin{tabular}{|l} 
RR \\
$\mathrm{Cl}(\mathrm{L}-\mathrm{U})$
\end{tabular} & Signif. \\
\hline \multirow{6}{*}{ Total visits } & \multirow{3}{*}{$\begin{array}{l}\text { Av. } \\
\text { Córdoba }\end{array}$} & $\mathrm{CO}(\mathrm{ppm})$ & $\begin{array}{l}1.169 \\
(1.107-1.235)\end{array}$ & $* * *$ & \begin{tabular}{|l}
1.202 \\
$(1.139-1.2697)$
\end{tabular} & $* * *$ & $\begin{array}{l}1.199 \\
(1.136-1.266)\end{array}$ & $* * *$ & $\begin{array}{l}1.189 \\
(1.127-1.255)\end{array}$ & $* * *$ \\
\hline & & $\mathrm{PM}_{10}\left(\mu \mathrm{g} / \mathrm{m}^{3}\right)$ & $\begin{array}{l}0.998 \\
(0.997-0.999)\end{array}$ & $* * *$ & \begin{tabular}{|l}
0.998 \\
$(0.997-0.999)$
\end{tabular} & $* *$ & \begin{tabular}{|l|}
0.998 \\
$(0.996-0.999)$
\end{tabular} & $* * *$ & \begin{tabular}{|l}
0.997 \\
$(0.996-0.998)$
\end{tabular} & $* * *$ \\
\hline & & $\mathrm{NO}_{2}(\mathrm{ppb})$ & & & \begin{tabular}{|l}
0.999 \\
$(0.998-1.000)$
\end{tabular} & * & $\begin{array}{l}0.999 \\
(0.998-1.000)\end{array}$ & * & & \\
\hline & \multirow{3}{*}{ La Boca } & $\mathrm{CO}(\mathrm{ppm})$ & \begin{tabular}{|l}
1.134 \\
$(1.032-1.25)$
\end{tabular} & ** & & & \begin{tabular}{|l|}
1.094 \\
$(0.995-1.203)$
\end{tabular} & & $\begin{array}{l}1.232 \\
(1.125-1.349)\end{array}$ & 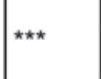 \\
\hline & & $\mathrm{PM}_{10}\left(\mu \mathrm{g} / \mathrm{m}^{3}\right)$ & $\begin{array}{l}0.998 \\
(0.997-0.999)\end{array}$ & *** & $\begin{array}{l}0.999 \\
(0.998-1.000)\end{array}$ & * & \begin{tabular}{|l|}
0.997 \\
$(0.996-0.999)$
\end{tabular} & $* * *$ & \begin{tabular}{|l}
0.996 \\
$(0.995-0.997)$
\end{tabular} & $* * *$ \\
\hline & & $\mathrm{NO}_{2}$ (ppb) & $\begin{array}{l}1.002 \\
(1.000-1.004)\end{array}$ & * & \begin{tabular}{|l}
1.003 \\
$(1.000-1.004)$
\end{tabular} & $* *$ & $\begin{array}{l}1.004 \\
(1.002-1.005)\end{array}$ & $* * *$ & & \\
\hline \multirow{6}{*}{$\begin{array}{l}\text { Visits for } \\
\text { ALRTI mm7 }\end{array}$} & \multirow{3}{*}{$\begin{array}{l}\text { Av. } \\
\text { Córdoba }\end{array}$} & $\mathrm{CO}(\mathrm{ppm})$ & \begin{tabular}{|l}
1.395 \\
$(1.077-1.807)$
\end{tabular} & * & \begin{tabular}{|l}
1.537 \\
$(1.187-1.992)$
\end{tabular} & $* *$ & $\begin{array}{l}1.640 \\
(1.267-2.124)\end{array}$ & $* * *$ & \begin{tabular}{|l}
1.694 \\
$(1.310-2.192)$
\end{tabular} & $* * *$ \\
\hline & & $\begin{array}{l}\mathrm{PM}_{10} \\
\left(\mu \mathrm{g} / \mathrm{m}^{3}\right)\end{array}$ & $\begin{array}{l}1.006 \\
(1.001-1.010)\end{array}$ & * & & & & & & \\
\hline & & $\mathrm{NO}_{2}$ (ppb) & $\begin{array}{l}0.992 \\
(0.986-0.998)\end{array}$ & * & \begin{tabular}{|l}
0.991 \\
$(0.985-0.997)$
\end{tabular} & ** & \begin{tabular}{|l|}
0.990 \\
$(0.984-0.997)$
\end{tabular} & *** & \begin{tabular}{|l}
0.991 \\
$(0.984-0.997)$
\end{tabular} & ** \\
\hline & \multirow{3}{*}{ La Boca } & $\mathrm{CO}(\mathrm{ppm})$ & & & \begin{tabular}{|l}
1.551 \\
$(1.006-2.390)$
\end{tabular} & * & \begin{tabular}{|l|}
1.773 \\
$(1.151-2.728)$
\end{tabular} & *** & $\begin{array}{l}1.916 \\
(1.245-2.948)\end{array}$ & $* *$ \\
\hline & & $\begin{array}{l}\mathrm{PM}_{10} \\
\left(\mu \mathrm{g} / \mathrm{m}^{3}\right)\end{array}$ & & & & & & & \begin{tabular}{|l}
0.994 \\
$(0.989-1.000)$
\end{tabular} & * \\
\hline & & $\mathrm{NO}_{2}$ (ppb) & & & & & & & & \\
\hline
\end{tabular}

Empty cells correspond to assessments that did not show a correlation.

RR: relative risk.

Significance codes: ${ }^{* * *} \leq 0.001,{ }^{* *} \leq 0.01,{ }^{*} \leq 0.05$.

Visits for ALRTI mm7: visits for acute lower respiratory tract infection, 7-day moving mean.

ppb: parts per billion.

ppm: parts per million.

CO: carbon monoxide.

$\mathrm{PM}_{10}$ : particulate matter $<10 \mu$.

$\mathrm{NO}_{2}$ : nitrous dioxide. 
residential, urban industrial, and high-traffic areas. ${ }^{13}$ The circulation of pollutants in the city and their dispersion to the surrounding areas is influenced by the wind and conditioned by the height of the temperature inversion layer, and varies from day to day. However, the data obtained from the stations, both in average and separately, provide information about the quality of the air to which the city and surrounding area populations are exposed.
More accurate studies should be done, which would require pollutant dispersion models and/ or specific monitoring, but this is beyond the scope of this study. It is worth noting that, in an ecological study of this type, the research subject is the population as a whole, so it bears the limitations entailed by it. ${ }^{18}$

Although it was not possible to verify it in our study, it does not mean that air quality does

TABLE 3. Risk for general visits and visits for acute lower respiratory tract infection based on pollutant increase, considering each monitoring station (4-, 5-, 6-, and 7-day lags)

\begin{tabular}{|c|c|c|c|c|c|c|c|c|c|c|}
\hline & & & 4-day lag & & 5-day lag & & 6-day lag & & 7-day lag & \\
\hline & & & \begin{tabular}{|l} 
RR \\
$\mathrm{Cl}(\mathrm{L}-\mathrm{U})$
\end{tabular} & Signif. & $\begin{array}{l}\text { RR } \\
\mathrm{Cl}(\mathrm{L}-\mathrm{U})\end{array}$ & Signif. & $\begin{array}{l}\text { RR } \\
\mathrm{Cl}(\mathrm{L}-\mathrm{U})\end{array}$ & Signif. & $\begin{array}{l}\text { RR } \\
\mathrm{Cl}(\mathrm{L}-\mathrm{U})\end{array}$ & Signif. \\
\hline Total visits & $\begin{array}{l}\text { Av. } \\
\text { Córdoba }\end{array}$ & $\mathrm{CO}$ (ppm) & \begin{tabular}{|l|}
1.153 \\
$(1.092-1.218)$
\end{tabular} & *** & \begin{tabular}{|l|}
1.241 \\
$(1.175-1.310)$
\end{tabular} & *** & \begin{tabular}{|l|}
1.252 \\
$(1.186-1.321)$
\end{tabular} & *** & \begin{tabular}{|l|}
1.175 \\
$(1.113-1.241)$
\end{tabular} & $* * *$ \\
\hline & & $\begin{array}{l}\mathrm{PM}_{10} \\
\left(\mu \mathrm{g} / \mathrm{m}^{3}\right)\end{array}$ & $\begin{array}{l}0.998 \\
(0.997-0.999)\end{array}$ & ** & $\begin{array}{l}0.998 \\
(0.997-0.999)\end{array}$ & *** & \begin{tabular}{|l|}
0.998 \\
$(0.997-0.999)$
\end{tabular} & *** & \begin{tabular}{|l|}
0.998 \\
$(0.997-1.000)$
\end{tabular} & ** \\
\hline & & $\mathrm{NO}_{2}$ (ppb) & & & & & & & \begin{tabular}{|l|}
0.998 \\
$(0.997-1.000)$
\end{tabular} & ** \\
\hline & La Boca & $\mathrm{CO}(\mathrm{ppm})$ & \begin{tabular}{|l|}
1.151 \\
$(1.049-1.264)$
\end{tabular} & ** & & & & & & \\
\hline & & $\begin{array}{l}\mathrm{PM}_{10} \\
\left(\mu \mathrm{g} / \mathrm{m}^{3}\right)\end{array}$ & $\begin{array}{l}0.997 \\
(0.996-0.999)\end{array}$ & *** & $\begin{array}{l}0.998 \\
(0.997-0.999)\end{array}$ & ** & $\begin{array}{l}0.999 \\
(0.997-1.000)\end{array}$ & * & \begin{tabular}{|l|}
0.998 \\
$(0.997-0.999)$
\end{tabular} & *** \\
\hline & & $\mathrm{NO}_{2}(\mathrm{ppb})$ & \begin{tabular}{|l|}
1.003 \\
$(1.001-1.005)$
\end{tabular} & ** & \begin{tabular}{|l|}
1.002 \\
$(1.000-1.004)$
\end{tabular} & * & \begin{tabular}{|l|}
1.003 \\
$(1.000-1.005)$
\end{tabular} & * & \begin{tabular}{|l|}
1.002 \\
$(1.000-1.004)$
\end{tabular} & * \\
\hline $\begin{array}{l}\text { Visits for } \\
\text { ALRTI } \mathrm{mm7}\end{array}$ & $\begin{array}{l}\text { Av. } \\
\text { Córdoba }\end{array}$ & $\mathrm{CO}(\mathrm{ppm})$ & $\begin{array}{l}1.767 \\
(1.368-2.282)\end{array}$ & *** & $\begin{array}{l}1.800 \\
(1.395-2.324)\end{array}$ & **** & $\begin{array}{l}1.792 \\
(1.388-2.314)\end{array}$ & *** & $\begin{array}{l}1.734 \\
(1.341-2.243)\end{array}$ & *** \\
\hline & & $\begin{array}{l}\mathrm{PM}_{10} \\
\left(\mu \mathrm{g} / \mathrm{m}^{3}\right)\end{array}$ & & & & & & & & \\
\hline & & $\mathrm{NO}_{2}(\mathrm{ppb})$ & $\begin{array}{l}0.991 \\
(0.985-0.998)\end{array}$ & ** & $\begin{array}{l}0.992 \\
(0.986-0.998)\end{array}$ & ** & \begin{tabular}{|l|}
0.992 \\
$(0.986-0.999)$
\end{tabular} & * & & \\
\hline & La Boca & $\mathrm{CO}(\mathrm{ppm})$ & \begin{tabular}{|l|}
1.858 \\
$(1.208-2.859)$
\end{tabular} & ** & $\begin{array}{l}1.775 \\
(1.154-2.731)\end{array}$ & ** & \begin{tabular}{|l|}
1.662 \\
$(1.079-2.559)$
\end{tabular} & * & \begin{tabular}{|l|}
1.591 \\
$(1.033-2.449)$
\end{tabular} & * \\
\hline & & \begin{tabular}{|l|}
$\mathrm{PM}_{10}$ \\
$\left(\mu \mathrm{g} / \mathrm{m}^{3}\right)$
\end{tabular} & & & & & & & & \\
\hline & & $\mathrm{NO}_{2}(\mathrm{ppb})$ & & & & & & & & \\
\hline
\end{tabular}

Empty cells correspond to assessments that did not show a correlation.

RR: relative risk.

Significance codes: ${ }^{* *} \leq 0.001,{ }^{* *} \leq 0.01,{ }^{*} \leq 0.05$.

ALRTI mm7: visits for acute lower respiratory tract infection, 7-day moving mean.

ppb: parts per billion.

ppm: parts per million.

CO: carbon monoxide.

PM1: particulate matter $<10 \mu$.

$\mathrm{NO}_{2}$ : nitrous dioxide. 
not affect patients' health, but that the impact of daily variations is not reflected on the number of visits. Most likely, it is influenced by the size of the studied population.

It should be noted that the levels of environmental pollutants in the CABA are usually within acceptable ranges: as mentioned before, in the study period, very few times, pollutant levels exceeded the limits established by the national legislation (9 ppm in 8-hour averages and $35 \mathrm{ppm}$ in 1-hour averages for $\mathrm{CO}, 220 \mathrm{ppb}$ in 1-hour averages for $\mathrm{NO}_{2}$, and $150 \mu \mathrm{g} / \mathrm{m}$ in 24-hour averages for $\left.\mathrm{PM}_{10}\right) \cdot{ }^{2}$

In addition, on the one side, the geographic and wind characteristics of this region restrict the accumulation of air components; on the other side, the impact of climate (winter) on pediatric medical visits is so big that it may mask any other consideration..$^{20}$ A study that analyzed the information about patient's exact place of residence would provide additional elements to describe the relationship between air pollution and health in the area.

It is clear that visits for ALRTI increase significantly in the winter. This is consistent with the fact that, in a city with temperate climate like Buenos Aires, the main causative agents of ALRTI in children (RSV and influenza virus) circulate in the winter. ${ }^{21}$ Such seasonal variation for different diseases (pneumonia, acute otitis media, upper respiratory tract infections) has also been described recently in a study carried out in the USA. ${ }^{22}$

The difference observed in total visits per day of the week may be influenced by social dynamics. ${ }^{23,24}$ The fact that visits for ALRTI do not follow the same pattern supports this.

The establishment of a series with 7-day moving averages for the visits for ALRTI helped to mitigate the impact of the poor quality of certain data. ${ }^{25}$ However, the study evidenced the weakness of the current recording system for its implementation in this type of research. Possibly, the ongoing transition to electronic clinical records ${ }^{26}$ taking place in health facilities run by the Government of the Autonomous City of Buenos Aires will remarkably improve this. ${ }^{27}$

Our results confirm, once more, the evidence of the association between the winter season and the increase in the number of pediatric medical visits, and its implications for the management of health resources.

\section{CONCLUSION}

Although a correlation was observed between the level of certain pollutants and the number of visits, its impact is not relevant. The number of visits to the Emergency Department of a children's hospital for acute respiratory infections increased significantly in the winter.

\section{REFERENCES}

1. World Health Organization. The global burden of disease: 2004 update. Geneva: WHO; 2008. [Accessed on: May 29th, 2019]. Available at: https://www.who.int/healthinfo/ global_burden_disease/GBD_report_2004update_full.pdf.

2. Rosenzweig C, Karoly D, Vicarelli M, Neofoitis P, et al. Attributing physical and biological impacts to anthropogenic climate change. Nature. 2008; 453(7193):353-7.

3. Bono R, Romanazzi V, Bellisario V, Tassinari R, et al. Air pollution, aeroallergens and admissions to pediatric emergency room for respiratory reasons in Turin, northwestern Italy. BMC Public Health. 2016; 16(1):722.

4. Bernstein AS, Rice MB. Lungs in a warming world: climate change and respiratory health. Chest. 2013; 143(5):1455-9.

5. Ferrero F, Torres F, Abrutzky R, Ossorio MF, et al. Circulación del virus sincicial respiratorio en Buenos Aires. Su relación con el cambio climático global. Arch Argent Pediatr. 2016; 114(1):52-5.

6. Organización Mundial de la Salud. Calidad del aire y salud. [Accessed on: February 20 ${ }^{\text {th }}$, 2017]. Available at: http:// www.who.int/mediacentre/factsheets/fs313/es/.

7. Xu Z, Etzel RA, Su H, Huang C, et al. Impact of ambient temperature on children's health: a systematic review. Environ Res. 2012; 117:120-31.

8. Largeron $Y$, Staquet C. Persistent inversion dynamics and wintertime PM10 air pollution in Alpine valleys. Atmos Environ. 2016; 135:92-108.

9. Wanka E, Bayerstadler A, Heumann C, Nowak D, et al. Weather and air pollutants have an impact on patients with respiratory diseases and breathing difficulties in Munich, Germany. Int J Biometeorol. 2014; 58(2):249-62.

10. Abrutzky R, Dawidowski L, Matus P, Romero-Lankao P. Health Effects of Climate and Air Pollution in Buenos Aires: A First Time Series Analysis. J Environ Prot. 2012; 3:262-71.

11. Abrutzky R, Torres FA, Ossorio MF, Ferrero F. Impacto de la contaminación atmosférica y el clima en las consultas a un departamento de emergencias pediátrico en la Ciudad de Buenos Aires. Rev Fac Cienc Med Córdoba. 2017; 74(4):365-71.

12. Barry M, Annesi-Maesano I. Ten principles for climate, environment and respiratory health. Eur Respir J. 2017; 50(6):1701912.

13. Agencia de Protección Ambiental de la Cuidad de Buenos Aires. Red de Monitoreo. [Accessed on: April 17 $7^{\text {th }}$, 2019]. Available at: https://www.buenosaires.gob.ar/areas/ med_ambiente/apra/calidad_amb/red_monitoreo / mapa.php?menu_id=32434.

14. Costa S, Ferreira J, Silveira C, Costa C, et al. Integrating health on air quality assessment--review report on health risks of two major European outdoor air pollutants: PMand NO2. J Toxicol Environ Health B Crit Rev. 2014; 17(6):307-40.

15. Peng R, Dominici F, Louis T. Model choice in time series studies of air pollution and mortality. J R Stat Soc Ser A. 2006; 169(2):179-203.

16. Pepió Viñals M. Series temporales. Barcelona: Universitat Politecnica de Catalunya; 2001. 
17. Schvartsman C, Amador Pereira L, Ferreira Braga A, Farhat SC. Seven-day cumulative effects of air pollutants increase respiratory ER visits up to threefold. Pediatr Pulmonol. 2017; 52(2):205-12.

18. Morgenstern H. Uses of ecologic analysis in epidemiologic research. Am J Public Health. 1982; 72(12):1336-44.

19. Decreto N. ${ }^{\circ} 198 / 06$, Anexos, reglamentario de la Ley 1356/04. Boletín Oficial de la Ciudad de Buenos Aires N. ${ }^{\circ}$ 2394. Buenos Aires, Argentina, 8 de marzo de 2006. [Accessed on: October 23 $\left.{ }^{\text {rd }}, 2018\right]$. Available at: http:/ / www.buenosaires.gob.ar/areas/leg_tecnica/sin/imagen. php?idn=83624\&idf $=1$.

20. Abrutzky R, Dawidowski L, Murgida A, Natenzon CE. Contaminación del aire en la Ciudad Autónoma de Buenos Aires: el riesgo de hoy o el cambio climático futuro, una falsa opción. Cien Saude Colet. 2014; 19(9):3763-73.

21. Marcone DN, Durand LO, Azziz-Baumgartner E, Vidaurreta S, et al. Incidence of viral respiratory infections in a prospective cohort of outpatient and hospitalized children aged $\leq 5$ years and its associated cost in Buenos Aires, Argentina. BMC Infect Dis. 2015; 15:447.

22. Lipsett SC, Monuteaux MC, Fine AM. Seasonality of Common Pediatric Infectious Diseases. Pediatr Emerg Care. 2018 [Epub ahead of print].
23. Faryar KA. The Effects of Weekday, Season, Federal Holidays, and Severe Weather Conditions on Emergency Department Volume in Montgomery County, Ohio. Wright State University, Dayton, Ohio. 2013. [Accessed on: October $\left.18^{\text {th }}, 2018\right]$. Availableat:https: / / corescholar.libraries.wright. $\mathrm{edu} / \mathrm{cgi} /$ viewcontent.cgi article $=1094 \&$ context $=\mathrm{mph}$.

24. Sun Y, Heng BH, Seow YT, Seow E. Forecasting daily attendances at an emergency department to aid resource planning. BMC Emerg Med. 2009; 9:1.

25. Bello PLD, Martinez CS. Una metodología de series de tiempo para el área de la salud: caso práctico. Rev Fac Nac Salud Pública. 2007; 25(2):117-22.

26. Tillmann T, Gibson AR, Scott G, Harrison O, et al. Systems Medicine 2.0: potential benefits of combining electronic health care records with systems science models. J Med Internet Res. 2015; 17(3):e64.

27. Ley N. ${ }^{\circ} 5669$ de Historia Clínica Electrónica. Boletín Oficial de la Ciudad de Buenos Aires. N ${ }^{\circ}$ 5019. Buenos Aires, Argentina, 27 de octubre de 2016. [Accessed on: October $\left.18^{\text {th }}, 2018\right]$. Available at: http:/ / www2.cedom.gob.ar/es / legislacion/normas/leyes/ley5669.html. 